\title{
THE AFTEREFFECTS OF MÜLLER-LYER AND PONZO ILLUSIONS: DIFFERENCES REVEALED IN SENSORIMOTOR DOMAIN
}

\author{
Vsevolod Lyakhovetskii ${ }^{1, \#}$ and Valeriia Karpinskaia ${ }^{2}$ \\ ${ }^{1}$ Pavlov Institute of Physiology, Russian Academy of Sciences, St. Petersburg, 199034, Makarova Emb., 6, RUSSIA \\ 2 St. Petersburg State University, St. Petersburg, 199034, Makarova Emb., 6, RUSSIA \\ \# Corresponding author, v_la2002@mail.ru
}

Communicated by Ivars Lācis

\begin{abstract}
Either effects or aftereffects of visual illusions are well studied at the visual domain while there are few studies of aftereffects at the motor tasks such as grasping or pointing at the illusory. The aftereffects of Müller-Lyer and Ponzo illusions in the sensorimotor domain were studied. We used four illusions: two versions of Müller-Lyer illusions (upper/bottom shafts appear longer) and two versions of Ponzo illusions (classical and inverted, upper/bottom shafts appear longer). They were presented to four experimental groups, each type to one of the groups. A fifth group was shown neutral stimuli (two horizontal lines, one under another). At first, one of the above described stimuli was presented ten times. Then, for testing the aftereffect, the neutral stimuli were presented thirty times. After the disappearance of each stimulus, the participant moved his/her right hand across the touch screen along its upper and lower shafts. The participants of all experimental groups experienced significant illusions, but only the classical Ponzo illusion caused significant long-time assimilative aftereffect. These results reveal the existence of an illusory aftereffect in the sensorimotor domain. Moreover, it depends on the type of visual illusion, thereby supporting the hypothesis of origin of the different visual illusions at different levels of the visual system.
\end{abstract}

Key words: aftereffect, Müller-Lyer, Ponzo, sensorimotor domain.

\section{INTRODUCTION}

Following Uznadze (Bjalava, 1966) and Piaget (Piaget and Lambercier, 1944) there have been many studies investigating the aftereffect of illusions. However, only a few of them have used visual illusions, although visual illusions are very popular stimuli in other domains of visual science. Moreover, usually only the Müller-Lyer illusion was used (Pollack, 1964; Kostandov et al., 1998; Valerjev and Gulan, 2013). It was supposed that different groups of visual illusions have different mechanisms (Coren et al., 1976; Deręgowski, 2015). For example, the Ponzo illusion is in the group "cognitive contrast illusions" and Müller-Lyer illusion is in the group "overestimation illusions" (Coren et $a l .$, 1976). Thus, the use of different illusions for studying aftereffects is of great interest.

Usually the direction of the aftereffect is opposite to the direction of the effect, i.e. the aftereffect is negative or contrasting compared to the effect of the original stimulus. For example, after a heavy load, the next load seems easier (Bjalava, 1966) or the line that temporally succeeds the inward fins of Müller-Lyer arrows seems longer, while the line succeeding the outward fins of Müller-Lyer arrows seems shorter (Valerjev and Gulan, 2013). Rarely, the direction of the aftereffect coincides with the direction of the effect, i.e. the aftereffect is positive or assimilative. It is assumed that the direction of aftereffect may depend on the domain (visual or sensorimotor) (Leontiev and Zaporogec, 1945; Kasatov and Obvinceva, 2001). Previously, we observed a positive aftereffect using the stimulus set consisting of both Müller-Lyer and Ponzo illusions for participants who estimated the size of the stimuli with the help of their right hand (Karpinskaia and Lyakhovetskii, 2014; Karpinskaia et al., 2016). The aim of the current study was to verify and to clarify the origins of our previous results. Thus, we presented different illusions to different groups of participants to study the possible aftereffect of each illusion separately in the sensorimotor domain.

\section{MATERIALS AND METHODS}

Different illusions were presented for four experimental groups, one to each group: Müller-Lyer illusion, upper/bottom shaft appears longer (see Fig. 1A and 1B), classical 


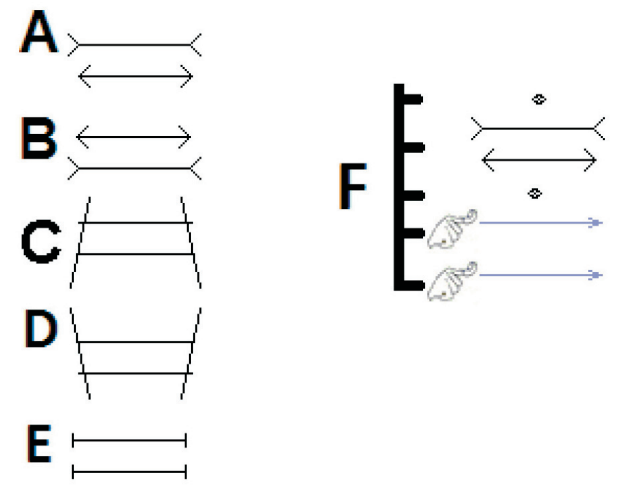

Fig. 1. Stimuli and methods. A, B - two versions of the Muller-Lyer illusion, C - classical Ponzo illusion, D - inverted Ponzo illusion, E - neutral stimulus, F - schemata of the experimental procedure.

Ponzo illusion (see Fig. 1C), and inverted Ponzo illusion, in which bottom shaft appears longer (see Fig. 1D). Neutral stimuli consisting of two shafts without any flanks were used for a control group (see Fig. 1E). Five groups of ten right-handed psychology students and postgraduates (four males and six females in each group, aged $26.3 \pm 2.1$ ) from St. Petersburg State University participated in the experiment. All participants had normal or corrected vision. The dominated hand was determined by the Edinburgh handedness inventory (Oldfield, 1971). The distance between the participant and the touch screen monitor was $80 \mathrm{~cm}$.

The design of the experiment was typical for study of aftereffects; the fixed set method was used. During the set acquisition trials, stimuli that presumably elicit the aftereffects were presented several times. Then, in the critical trial, neutral stimuli were presented, which due to previously presented stimuli might deviate from their usual perceptual characteristics. The task of the participants was to reproduce by hand on the empty touch screen monitor the central shafts of the previously presented stimulus. In the set acquisition trials, one of the above mentioned stimuli was presented ten times: two times $\times$ five different lengths of the shafts $(4.5 \mathrm{~cm}, 6 \mathrm{~cm}, 7.5 \mathrm{~cm}, 9 \mathrm{~cm}, 11.5 \mathrm{~cm}$ or 4.3 arc. deg., 5.7 arc. deg., 7.2 arc. deg., 8.6 arc. deg., 10.9 arc. deg. respectively). Then, in the critical trial, neutral stimuli were presented thirty times (all shafts of neutral stimuli had equal length, $6 \mathrm{~cm}$ or 5.7 arc. deg.).

We used different length of shafts in set acquisition trials to prevent the participant from learning the length of the shafts. The aim was to produce a perceptual set: upper shaft looks longer than the lower one, or the opposite contrary (depended on the experimental group). We used different shaft lengths so that the participants did not learn to move their hand according to the one length of the shafts, but instead learned the general rule "longer-shorter" on the base of the illusory different stimuli. We used equal length in all critical trials, because we wanted to measure the resistance of the perceptual set (Kostandov, 1999) and to compare trials. The aim of using neutral stimuli of $6 \mathrm{~cm}$ length (instead of $7.5 \mathrm{~cm}$ ) in critical trials was to study the central grouping effect (Crawford et al., 2000). We expected that the lengths of the hand movements over both shafts of the neutral stimuli will shift to the mean length of the shafts in the set acquisition trials.

The instruction to the participant was: "Thank you for your participating in our experiment. During the experiment you will see pairs of shafts. Please, remember their length and then reproduce it by hand on the empty screen after their disappearance. Try to be accurate." The person leading the experiment pressed a button on a keyboard after he was assured the participant had seen the stimulus clearly, and the stimulus disappeared. Immediately after the disappearance of each stimulus, the participant moved his/her right hand across the touch screen monitor, first along the upper shaft and then along the lower shaft from left to right (see Fig. $1 F)$. The experiment was performed without feedback.

We recorded the start and end points of the participant's hand movements and the times of their touch. The coordinates of the points were used to calculate the strength of the illusion and the aftereffect: this was the difference between the reproduced lengths of the upper and lower shafts. The times were used to calculate the mean speed of the hand movements over both shafts. The significance of illusory effect and the significance of mean speed differences were estimated using the Mann-Whitney U test $(p<0.05)$ for all trials of each group as a whole. The significance of aftereffect was estimated using the Mann-Whitney U test $(p<$ 0.05 ) for each trial of each group. This non-parametric criterion was chosen because the studied variables were not distributed normally. The significance of effects, mean \pm standard errors and linear trends of aftereffects were calculated with Matlab R2010b (Matworks Inc., version 7.11.0.584).

\section{RESULTS}

The mean strength of illusions and neutral stimuli, their mean aftereffects and their standard errors are presented in Figure 2A. All values are expressed as percentage of the length of the stimuli shafts. Negative values indicate that the bottom shaft of stimuli appears longer than the top shaft (see Fig. 1B and 1D). The figure shows that the participants of all experimental groups experienced significant illusions. In the Müller-Lyer illusion, the bottom shaft appeared longer and had maximal strength $7.16 \pm 0.89 \%$. The inverted Ponzo illusion was slightly stronger than the classical Ponzo illusion $(6.65 \pm 0.68 \%$ vs $5.69 \pm 1.32 \%)$. In the Müller-Lyer illusion, the upper shaft appeared longer and had the lowest strength, $2.31 \pm 0.80 \%$, which was significantly lower than the strength of the three other illusions used. The participants of the control group did not experience any difference between the lengths of the shafts of the neutral stimulus $(0.85 \pm 0.85 \%)$. The standard errors of estimations of illusions and neutral stimulus are approximately equal.

A significant central grouping effect was observed only after the neutral stimuli $(4.9 \% \pm 1.2 \%)$; the participants overestimated equally the two shafts of the neutral stimuli. A 

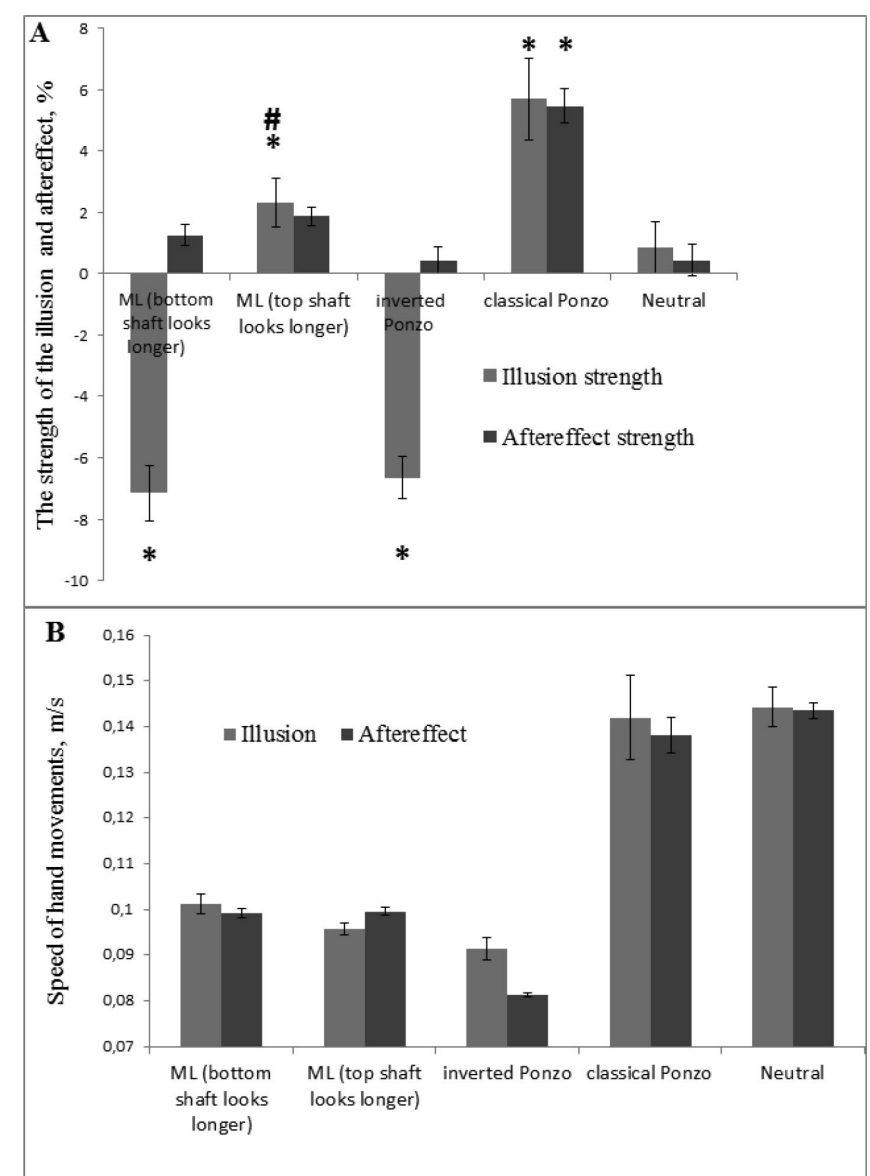

Fig. 2. A. The mean strength of the Müller-Lyer illusion, the inverted and classical Ponzo illusion, the neutral stimuli and their mean aftereffects. All values are in the percentage of the length of the stimuli shafts. *, significant difference from zero; \#, significant difference relative to other types of the illusions. The negative values indicate that the bottom shaft of stimuli appears longer than the top shaft. B. The mean speed of hand movement over the central shafts of the Müller-Lyer illusion, the inverted and classical Ponzo illusion, neutral stimuli and neutral stimuli it succeeding. Ordinate $-\mathrm{m} / \mathrm{s}$.

more detailed description of this effect is outside the scope of this paper.

The mean speeds of hand movement over illusions and neutral stimuli at the set acquisition trials and the critical trials, with their standard errors, are presented in Figure 2B. The speed of hand movement over the blank touch screen depended on the type of the previously presented stimulus. In the set acquisition trials, the slowest movement was made over the central shafts of the inverted Ponzo illusion $(0.09 \pm$ $0.002 \mathrm{~m} / \mathrm{s}$ ), and the fastest movement over the central shafts of the classical Ponzo illusion and neutral stimuli $(0.14 \pm$ $0.009 \mathrm{~m} / \mathrm{s}$ and $0.14 \pm 0.004 \mathrm{~m} / \mathrm{s}$ respectively). The speed of hand movement over the central shafts of the two versions of Müller-Lyer illusion was similar $(0.10 \pm 0.002 \mathrm{~m} / \mathrm{s}$ and $0.10 \pm 0.001 \mathrm{~m} / \mathrm{s})$. A similar distribution of the speed among the groups occurred in the critical trials: the slowest movement was made over the central shafts of the neutral stimuli presented after the inverted Ponzo illusion $(0.08 \pm$ $0.001 \mathrm{~m} / \mathrm{s}$ ) and the fastest movement over the central shafts of the neutral stimuli presented after the classical Ponzo il- lusion and after the neutral stimuli $(0.14 \pm 0.003 \mathrm{~m} / \mathrm{s}$ and $0.14 \pm 0.002 \mathrm{~m} / \mathrm{s}$ respectively). The speed of hand movement over the central shafts of the neutral stimuli presented after two versions of the Müller-Lyer illusion were similar $(0.10 \pm 0.001 \mathrm{~m} / \mathrm{s})$ and significantly faster than the speed of hand movement over the central shafts of the neutral stimuli presented after the inverted Ponzo illusion.

The average dynamics of aftereffects are presented in Figure 3 , which shows the relative length of the neutral stimuli shafts in the trials. Figures $2 \mathrm{~A}$ and $3 \mathrm{C}$ show that the participants of the control group did not experience any aftereffect $(0.3 \pm 0.5 \%)$; an aftereffect was also lacking for both versions of the Müller-Lyer illusion and for the inverted Ponzo illusion (see Fig. 3A and 3B, mean aftereffects were $1.24 \pm$ $0.35 \%, 1.86 \pm 0.31 \%$, and $0.44 \pm 0.44 \%$, respectively; the means of thirty trials did not differ significantly from zero). However, the classical Ponzo illusion caused significant long-lasting positive aftereffect, as the participants overestimated length of the upper shaft of neutral stimulus (5.6 \pm $0,56 \%)$. The size of this aftereffect did not depend on the strength of the illusion $\left(r^{2}=0.44, p>0.05\right)$ and did not vary during the thirty trials, remaining positive (linear trend non-significant, $r=0.01, p>0.05$ ) (see Fig. $3 \mathrm{~B}$ ).

\section{DISCUSSION}

The absence of significant difference between the estimates of the lengths of the lower and upper shafts of the neutral stimuli showed that the participants did not have any initial bias to incorrect estimation of the upper or lower part of the figures. Morgan et al. (1990) found that sensitivities (i.e. thresholds or just noticeable differences) were generally not affected by the introduction of illusory biases in the visual domain. These sensitivities may be estimated by the dispersion of answers of the participants. The standard errors of estimates of illusions and neutral stimuli among the five groups were similar, confirming that in the sensorimotor domain, visual illusion affects the length of the hand movement but not its dispersion (Morgan et al. 1990).

The Müller-Lyer and Ponzo illusions were chosen because they have similar perceptual results: two equal length lines appear to differ, allowing us to compare the strength of the illusory effect using different configurations. There are many theories explaining the origin of one or the other of these illusions. However, they are considered together only in a small number of studies. There are several classifications of visual illusions. Piaget and Fress (1963) distinguished the effects of field and those of perceptual activity according to the developmental changes in intensity of visual illusions; the effects of the former declines while the latter progresses with age. The effect of field is involved in the Müller-Lyer illusion (Piaget and Fress, 1963), and in the classical Ponzo illusion (Wagner, 1977), as their strength declines with age. Gregory (2009) also regarded these two illusions as examples of the same effect: the effect of perspective cues. However, Coren et al. (1976) classified these two illusions in different groups. More recently it was pro- 
$\mathbf{A}$

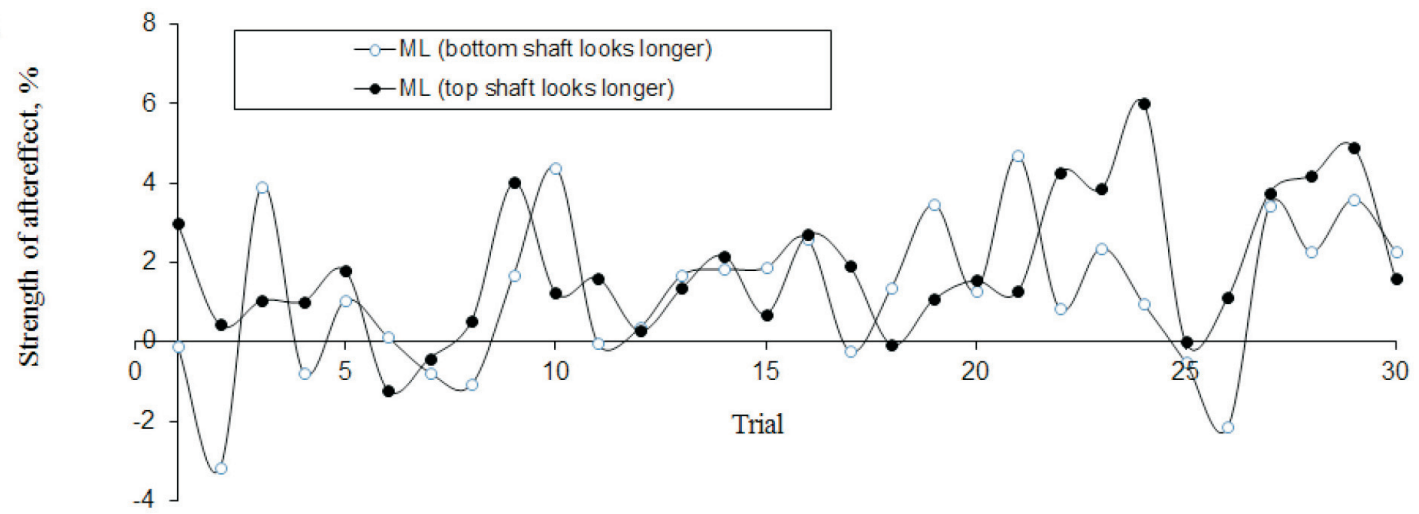

B

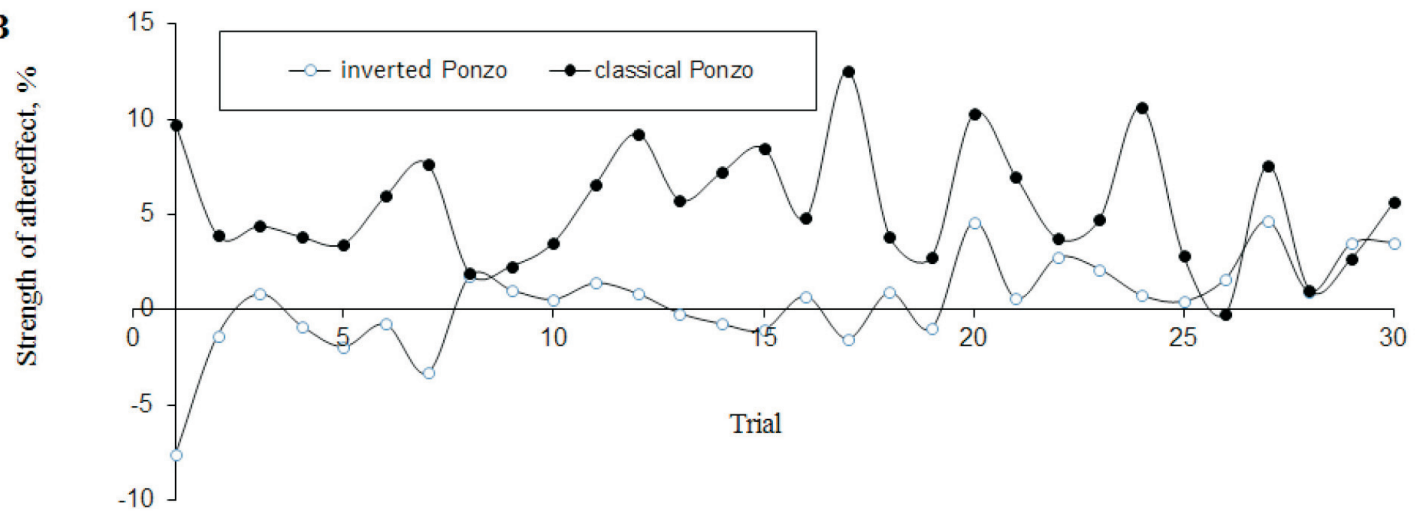

$\mathrm{C}$

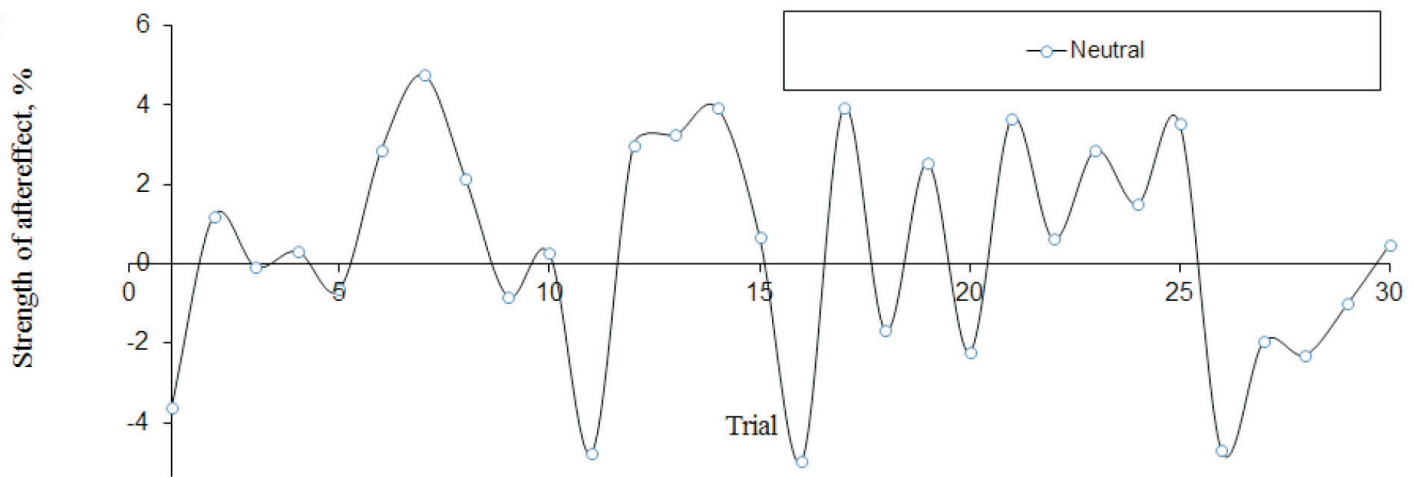

Fig. 3. The average dynamics of aftereffect. A. Two versions of Müller-Lyer illusions. B. Inverted and classical Ponzo illusion. C. Neutral stimuli. Abscissa the trial number, ordinate - the percentage length of the neutral stimuli shafts.

posed that the Müller-Lyer and Ponzo illusions are both related to perception of depth, but this relationship is not of the same type (Deręgowski, 2015).

The dependence of the speed of hand movement on the stimulus type indicates that the hand movements were not planned feed-forward during the presentation of the visual stimuli (in such a case the speed of hand movement would be similar among the stimulus types). In contrast, hand movement was performed with constant feed-back, i.e. under constant conscious control. Moreover, the speed of hand movement at the critical stage was determined by the stimuli presented at the set stage. We propose that conscious control is minimal for the simplest stimuli used in our experiment, the neutral stimuli, and that presumably the aftereffect is possible only when conscious control is minimal, i.e. after the classical Ponzo illusion when hand movement was faster than after other illusions.
Interestingly, as in work of Shoshina et al. (2011) we did not observe the well-known weakness of the inverted Ponzo illusion compared with its classical version (Deręgowski, 2015), as the relative strength of these two versions was similar. However, the presence of the aftereffect only after the classical Ponzo illusion and the significant difference between mean speed of hand movement over the central shafts of the classical Ponzo illusion and the inverted Ponzo illusion suggest that different versions of Ponzo illusions have different mechanisms. The significant difference between mean speed of hand movement over the central shafts of the classical Ponzo illusion and the Müller-Lyer illusion and the presence of aftereffect only after the classical Ponzo illusion suggest that they originated at different levels of processing of the visual scene. Clinical data on strength of these two illusions in schizophrenia support this hypothesis, as persons suffering from schizophrenia for a short time 
were less affected by both versions of the Ponzo illusion and more affected by the Müller-Lyer illusion, compared to mentally healthy subjects (Shoshina et al., 2011). Also, the existence of the Müller-Lyer illusion in the haptic domain is well established, while the origin of the classical Ponzo illusion is contradictory (Gentaz and Hatwell, 2004).

Contrary to the popular Milner thesis about two subsystems for perception and action (Aglioti et al., 1995; Milner and Goodale, 1995), but in line with our previous results (Karpinskaia and Lyakhovetskii, 2014) and the results of many other sensorimotor experiments (Bruno, 2001; Carey, 2001), the participants of all experimental groups experienced significant illusions. In the current study, to reduce duration of the experiment, we asked participants to trace the shafts only on the blank screen after the stimulus disappeared. Previously, we also recorded the illusions' strength at memorisation stage (i.e. when the participant observed the stimuli and his/her hand together). Surprisingly, at the memorisation stage, the participants experienced only the Müller-Lyer illusion, but not the classical Ponzo illusion, thus repeating partially the Milner results (Karpinskaia and Lyakhovetskii, 2013; Karpinskaia and Lyakhovetskii, 2014). Thus, the type of the task (grasping or pointing), even within a single sensorimotor domain, strongly influences the mechanisms of visual processing of perceived illusion. Moreover, continuing Milner's ideas, it is possible to propose multilevel mechanisms of visual processing: the processing of the grasping involves only its lowest level (where both illusions are absent), the processing of pointing without the use of motor memory activates some medium levels (where the classical Ponzo illusion is absent), and the processing of the pointing with the use of memory involves its highest level (where both the Müller-Lyer and the classical Ponzo illusions exist).

As expected, the participants of the control group did not experience an aftereffect. In contrast to the visual domain when the aftereffect of Müller-Lyer illusion is negative (Pollack, 1964; Kostandov et al., 1998; Valerjev and Gulan, 2013), the aftereffect in the sensorimotor domain is absent for both versions of Müller-Lyer illusion. Thus, the positive aftereffect observed in our previous studies (Karpinskaia and Lyakhovetskii, 2014) may be explained by the presence of the stimulus inducing the classical Ponzo illusion.

In the first studies examining the aftereffect, the duration of aftereffects was measured in a small number of trials (Bjalava, 1966). A long-lasting aftereffect, similar to aftereffect of the classical Ponzo illusion, was obtained in our study for the Müller-Lyer illusion in the visual domain (Kostandov et al., 1998), as $70 \%$ of participants estimated the size of neutral stimuli incorrectly during 6-30 trials.

Does the direction of the aftereffect depend on the domain? Bjalava (1966) stated that the positive aftereffect is more probable when the difference between stimuli giving rise to it is small. This statement can relate to the question raised, as it was shown that the strength of illusions is smaller in the pointing tasks compared with the perceptual tasks
(Bruno, 2001). Kasatov and Obvinceva (2001) proposed that the negative aftereffects emerge at the sensorimotor level while the positive aftereffects emerge at the perceptual level. In contrast, Leontiev and Zaporozhets (1945) showed that hands assimilated to equal weights in the Uznadze experiment before the participant gave the correct verbal response. Thus, the hands of the participant did not expect an aftereffect but the participant did (as in the two subsystems conception proposed much later). It was assumed, as shown in our study, that the negative aftereffects emerge at the perceptual level while the positive aftereffects emerge at the sensorimotor level. Thus, in support of earlier studies (Leontiev and Zaporozhets, 1945; Kasatov and Obvinceva, 2001), we conclude that the domain of response affects the type and the existence of aftereffect.

As mentioned above, we do not know any studies that examined the aftereffects of visual illusions in the sensorimotor domain per se. However, there have been studies on the effect of illusions on sport skills. Witt et al. (2012) demonstrated using the Ebbinghaus illusion a difference in golf putting performance when the hole was surrounded by small circles, making it look larger, and when it was surrounded by large circles, making it look smaller. The success of golf putting was more effective with the "larger" hole than with the "small" one. Chauvel et al. (2015) using the same illusion and the same task examined whether practicing would have not only immediate effects on performance, but also longer-lasting effects on motor learning. One day after a training session, the participants performed the golf putting task without visual illusions. The accuracy in this test session was greater for the group that had practiced with the hole that was perceived as larger. Thus, the authors suggested that the "larger" target led to more effective learning. We may propose with a certain degree of caution that such influence of the visual illusions onto the sport skills is contradictory.

Yet, in contrast to these earlier reports, Cańal-Bruland et al. (2016) observed that a group trained to perform a marble-shooting task with the Ebbinghaus illusion that made the target look smaller and a control group improved performance from pre- to post-test, whereas a group practicing with Ebbinghaus illusion that made the target appear larger did not show any improvement. Our previous results (Karpinskaia and Lyakhovetskii, 2016) are in good agreement with studies (Cańal-Bruland et al., 2016) suggesting that training of shooting a target that looks "smaller" due to a Ponzo illusion will lead to better results, comparing with a neutral target of the same size. We may propose with a certain degree of caution that such influence of the visual illusions onto the sport skills is assimilative, as in our current work.

The results of previous work on effect of visual illusions on the performance of the various motor tasks are summarised in Table 1. In general, the presence of this influence and its direction depends significantly on the task and the illusion used. 
THE INFLUENCE OF VISUAL ILLUSIONS ON THE PERFORMANCE OF VARIOUS MOTOR TASKS

\begin{tabular}{|c|c|c|c|}
\hline Authors & Illusion & Task & Effect \\
\hline $\begin{array}{l}\text { Witt et al., } 2012 \\
\text { Chauvel } \text { et al., } 2015\end{array}$ & Ebbinghaus & $\begin{array}{l}\text { To put golf balls into a target } \\
\text { circle. }\end{array}$ & $\begin{array}{l}\text { Self-efficacy was higher for those who } \\
\text { perceived the target area as being larger. }\end{array}$ \\
\hline Karpinskaia, Lyakhovetskii, 2014 & Müller-Lyer and classical Ponzo & $\begin{array}{l}\text { To trace the central shafts of these } \\
\text { illusions by the left/right hand }\end{array}$ & $\begin{array}{l}\text { The participants underestimated/overesti- } \\
\text { mated the neutral stimuli. }\end{array}$ \\
\hline Cańal-Bruland et al., 2016 & Ebbinghaus & Marble-shooting & $\begin{array}{l}\text { Self-efficacy was higher for those who } \\
\text { perceived the target area as being smaller. }\end{array}$ \\
\hline Karpinskaia, Lyakhovetskii, 2016 & Classical Ponzo & Gun shooting & $\begin{array}{l}\text { Self-efficacy was higher for those who } \\
\text { perceived the target area as being smaller. }\end{array}$ \\
\hline \multirow[t]{3}{*}{ Current work } & Müller-Lyer & \multirow{3}{*}{$\begin{array}{l}\text { To trace the central shafts } \\
\text { immediately after disappearance } \\
\text { of the illusion by the right hand }\end{array}$} & The aftereffect is absent. \\
\hline & Inverted Ponzo & & \\
\hline & Classical Ponzo & & A positive aftereffect exists. \\
\hline
\end{tabular}

\section{CONCLUSIONS}

These results reveal the existence of an illusory aftereffect in the sensorimotor domain. The speed of hand movement over the neutral stimuli in the critical stage depends on the type of visual illusion presented in the set stage. Moreover, the size of the aftereffect depends on the type of visual illusion, supporting the hypothesis of different origin of visual illusions in various levels of the visual system.

\section{ACKNOWLEDGEMENTS}

Financial support: Russian Humanitarian Scientific Fund 16-36-01008, Russian Foundation for Basic Research 1706-00473.

\section{REFERENCES}

Aglioti, S., DeSouza, J. F., Goodale, M. A. (1995). Size-contrast illusions deceive the eye but not the hand. Curr. Biol., 5 (6), 679-685.

Bjalava, I. Т. (1966). Psychology of Set and Cybernetics. [Бжалава, И. Т. Психология установки и кибернетика]. Nauka, Moscow. 250 pp. (in Russian)

Bruno, N. (2001). When does action resist visual illusions? Trends Cogn. Sci., 5 (9), 379-382.

Cańal-Bruland, R., van der Meer, Y., Moerman, J. Can visual illusions be used to facilitate sport skill learning? J. Motor Behav., 48, 385-389.

Carey, D. (2001). Do action systems resist visual illusions? Trends Cogn. Sci., 5 (3), 109-113.

Chauvel, G., Wulf, G., Maquestiaux, F. (2015). Visual illusions can facilitate sport skill learning. Psychonomic Bull. Rev., 22, 717-721.

Coren, S., Girgus, J. S., Erlichman, H., Hakstian, A. R. (1976). An empirical taxonomy of visual illusions. Percept. Psychophys., 20 (2), 129-137.

Crawford, L. E., Huttenlocher, J., Engebretson, P. H. (2000). Category effects on estimates of stimuli: Perception or reconstruction? Psychol. Sci., 11 (4), 280-284.

Deręgowski, J. B. (2015). Illusions within an illusion. Perception, 44 (12), 1416-1421.

Gentaz, E., Hatwell, Y. (2004). Geometrical haptic illusions: The role of exploration in the Müller-Lyer, vertical-horizontal, and Delboeuf illusions. Psychonomic Bull. Rev., 11 (1), 31-40.
Gregory, R. L. (2009). Seeing Through Illusions. Oxford University Press, Oxford. 357 pp.

Karpinskaia, V., Lyakhovetskii, V. (2013). The sensorimotor evaluation of perceptual illusions. Procedia Soc. Behav. Sci., 86, 323-327.

Karpinskaia, V., Lyakhovetskii, V. (2014). The differences in the sensorimotor estimation of the Ponzo and Mbller-Lyer illusions [Карпинская, В., Ляховецкий, В. Различия в сенсомоторной оценке иллюзий Понзо и Мюллера-Лайера]. Psikhologicheskie Issledovaniya [Психологические исследования], 7 (38), 3 (in Russian).

Karpinskaia, V., Lyakhovetskii, V., Allakhverdov, V., Shilov, Y. (2016). The peculiarities of perceptual set in sensorimotor illusions. Lecture Notes Comp. Sci., 9719, 706-711.

Kasatov, A. P., Obvinceva, A. V. (2001). Qualitative features of perceptual set, measured by estimation of the magnitude, and crossmodal selection [Касатов, А. П., Обвинцева, А. В. Качественные особенности проявления эффекта установки, измеренного методами оценки величины и кроссмодального подбора]. Psychol. Bull. Ural State Univ. [Психологический вестник Уральского государственного универсиmema], No. 2, 163-169 (in Russian).

Kostandov, E. A., Kurova, N. S., Cheremushkin E. A., Iakovenko, I. A. (1998). The role of unconscious sets formed on the basis of the perception of concrete visual stimuli and of illusory representations in conscious cognitive activity [Костандов, Э. А., Курова, Н. С., Черемушкин, Е.А., Яковенко, И. А. Роль неосознаваемых установок, формируемых на основе восприятия конкретных зрительных стимулов и иллюзорных представлений, в сознательной когнитивной деятельности]. Zhournal Vysshei Nervnoi Deiatelnosti im. I. P. Pavlova [Журнал высшей нервной деятельности им. И. П. Павлова], 48 (3), 438-448 (in Russian).

Kostandov, E. A. (1999) Formation of the perceptual set on the basis of illusory representations and at perception of concrete visual stimuli [Костандов, Э. А. Формирование установки на основе иллюзорных представлений и при восприятии конкретных зрительных стимулов]. Human Physiol. [Физиология человека], 25 (1), 5-14 (in Russian).

Leontiev, A. N., Zaporozhets, A. V. (1945) The Restoration of Movements. [Леонтьев, А. Н., Запорожец, А. В. Восстановление движений]. Sovetskaya nauka, Moscow. 231 pp. (in Russian).

Milner, D., Goodale, M. (1995). Visual Brain in Action. Oxford University Press, Oxford. 310 pp.

Morgan, M. J., Hole, G. J., Glennerster, A. (1990). Biases and sensitivities in geometrical illusions. Vis. Res., 30 (11), 1793-1810.

Oldfield, R. C. (1971). The assessment and analysis of handedness: The Edinburgh inventory. Neuropsychologia, 9 (1), 97-113. 
Piaget, J., Lambercier, M. (1944). Recherches sur le développement des perceptions: V. Essai sur un effet d' "Einstellung" survenant au cours de perceptions visuelles, successives (effet Usnadze). Arch. Psychol., 30, 139-196 (in French).

Piaget, J., Fress, P. (1963). Traité de psychologie expérimentale, 6, Perpception. Presses Universitaires de France, Paris. 210 pp. (in French).

Pollack, R. H. (1964). Simultaneous and successive presentation of elements of the Müller-Lyer figure and chronological age. Percept. Motor Skills, 19, 303-310.

Shoshina, I. I., Perevozchikova, I. N., Konkina, S. A., Pronin, S. V., Shelepin, Iu. E., Bendera, A. P. (2011). Features of perception of length of segments under conditions of Ponzo and Müller-Lyer illusions in schizophrenia [Шошина, И. И., Перевозчикова, И. Н., Конкина, С. А., Пронин, С. В., Шелепин, Ю. Е., Бендера, А. П. Особенности восприятия длины отрезков в условиях иллюзии Понцо и МюллераЛайера при шизофрении]. Zh. Vyssh. Nerv. Deiat. Im. I. P. Pavlova [Ж. Выси. Нерв. Деят. им. И. П. Павлова], 61 (6), 697-705 (in Russian).

Valerjev, P., Gulan, T. (2013). The role of context in Müller-Lyer illusion: The case of negative Müller-Lyer illusion. Rev. Psychol., 20, 29-36.

Wagner, D. A. (1977). Ontogeny of the Ponzo illusion: Effects of age, schooling, and environment. Int. J. Psychol., 12 (3), 161-176.

Witt, J. K., Linkenauger, S. A., Proffitt, D. R. (2012). Get me out of this slump! Visual illusions improve sports performance. Psychol. Sci., 23 (4), 397-399.

\section{MILLERA-LAIERA UN PONZO ILŪZIJU PĒCEFEKTI: SENSORI MOTORĀS ATBILDES LAIKĀ NOVĒROTĀS ATŠK̦IRĪBAS}

Redzes ilūziju efekti un pēcefekti ir plaši izpētīti saistībā ar vizuālo atbildi, savukārt ilūziju radītie pēcefekti motoros uzdevumos, kā satveršana vai parādīšana, paliek maz izpētīti. Šajā darbā tika pētīti Millera-Laiera un Ponzo ilūziju radītie pēcefekti sensori motorās atbildes laikā. Mēs izmantojām četras ilūzijas: divas Millera-Laiera ilūzijas versijas (augšējā vai apakšējā līnija izskatās garāka) un divas Ponzo ilūzijas versijas (klasiskā un apgrieztā, augšējā vai apakšējā līnija izskatās garāka). Tās tika rādītas četrām eksperimentālām grupām, katrs veids vienai grupai. Mums bija arī grupa, kurai tika rādīti neitrāli stimuli (divas horizontālas līnijas, viena zem otras). Sākumā viens no minētajiem stimuliem tika rādīts desmit reizes. Pēc tam, lai novērtētu pēcefektu, neitrālie stimuli tika rādīti trīsdesmit reizes. Pēc katra stimula pazušanas dalībnieks ar labo roku pārvilka pāri skārienjutīgam ekrānam, norādot augšējās un apakšējās līnijas garumu. Visu eksperimentālo grupu dalībnieki pieredzēja būtiskas ilūzijas, bet tikai klasiskā Ponzo ilūzija izraisīja nozīmīgu ilgtermiņa asimilācijas pēcefektu. Šie rezultāti apliecina ilūzijas radīta pēcefekta klātesamību sensori motorās atbildes laikā. Turklāt tas ir atkarīgs no redzes ilūzijas veida, kas atbalsta hipotēzi, ka dažādas redzes ilūzijas parādās dažādos redzes sistēmas līmeņos. 